\title{
POSISI BAHASA ARAB DI DUNIA ISLAM
}

\author{
Angga Pandapotan Nasution \\ Sekolah Tinggi Agama Islam Negeri (STAIN) Sorong, Papua Barat, Indonesia \\ Email: angganasution090@gmail.com
}

\begin{abstract}
ABSTRAK
Bahasa arab adalah suatu alat komunikasi yang ada di jazirah arab dan asia tengah. Bahasa arab juga merupakan bahasa Al-qur'an yakni kalam Allah SWT dan Hadist, kemahiran bahasa arab ada empat kemahiran yaitu kemahiran istima, berbicara, membaca dan menulis. Dari keempat kemahiran membaca tersebut yang penulis fokuskan dalam penelitian ini adalah kemahiran membaca. Metode pengumpulan data yang digunakan adalah tes lisan sebagai metode primer dan sebagai metode sekunder adalah metode observasi, interview dan data dokumentasi.
\end{abstract}

\section{PENDAHULUAN}

Hakikat manusia sebagai makhluk sosial mendorong manusia untuk saling berkomunikasi satu sama lain, berkomunikasi menggunakan bahasa, proses ini terjadi sejak manusia hadir di muka bumi ini Proses ini terjadi sejak manusia hadir dalam kehidupan, sejak itu pula terjadi proses pertukaran ide gagasan keterangan saran usul.

Secara umum, bahasa dapat didefinisikan sebagai usaha penyampain pesan antarmanusia. Ilmu bahasa tidak mengkaji proses penyampain pesan kepada makhluk yang bukan manusia (hewan dan tumbuh-tumbuhan). Bahasa terjadi dimana saja dan kapan saja. Wilayah bahasa bisa ada dalam makro dan mikro. Mulai dari dua orang, misalnya dalam hubungan "pacaran" antara beberapa orang misalnya dalam keluarga, antar banyak orang ,misalnya dalam suatu kampus atau partai politik. Banyak sekali orang atau melibatkan pihak dalam jumlah yang massif (bahasa massa).

Bahasa juga tidak hanya mempelajari pertukaran informasi atau pesan antara dua orang saja, bahasa juga dapat melibatkan banyak orang misalnya kelompok organisasi atau rakyat, bayangkan tanpa bahasa, sejarah peradaban manusia tak akan dapat maju sebagaimana mestinya. 


\section{PENDIDIKAN BAHASA ARAB DI PESANTREN}

Bahasa arab merupakan bahasa yang penting bagi masyarakat islam manapun, karna merupakan bahasa peribadatan, bahasa yang banyak digunakan oleh masyarakat islam dan dinyakini oleh khalayak ramai bahwa ia merupakan bahasa pilihan allah. Ini dapat diperhatikan dengan penggunaan bahasa arab pada ritual peribadatan dalam islam. Mana solat, haji dan perbagai aktiviti ibadah umat islam mesti menggunakaan bahasa arab. hal itu di mungkinkan karena adanya pengaruh al-qur'an.

Pesantren ialah lembaga pendidikan tradisional islam yang dimaksudkan untuk memahami,menghayati dan mengamalkan ajaran agama islam, peranannya seperti ini, maka pesantren yang menjalankan misi utama dalam bidang pendidikan seboleh bolehnya diarahkan sebagai projek perintis dan ejan untuk melakukan perubahan sosial bagi pembentuk masyarakat baru.

Dalam konteks pendidikan. tidak di temui adanya inovasi pendidikan yang dapat mengarah kepada perbaikan proses pendidikan bahasa arab yang telah ada, sementara kecenderungan dunia ketika ini adalah globalisasi, dimana ditandai dengan dengan penyebaran maklumat yang sangat cepat

Bahasa mempunyai tempat yang sangat khas dalam budaya masyarakat . demikian juga budaya mempunyai tempat yang sangat khas dalam bahasa masyarakat senantiasa memerlukan bahasa sebagai alat komunikasi yang dominan. Masyarakat merupakan kumpulan orang yang hidup bersama yang menghasilkan kebudayaan.

Metod ini di sebut metod langsung karna selama pelajarannya pengajaran langsung menggunakan bahasa asing yang diajarkan, sedangkan bahasa bahasa pelajar seboleh mungkin tidak boleh digunakan. Bahasa arab sebagai mata pelajaran di pesantren berdasarkan kurikulum berbasis kopetensi, kurikulum berbasis kompetensi bahasa arab menegaskan bahwa optimisme dan lingkungan sosial siswa akan menentukan tingkat belajar bahasa asing siswa

Prestasi belejar siswa pesantren di Indonesia biasanya di dapat dalam hasil ujian yang dilakukan oleh guru, sekolah maupu negara, evaluasi belajar sebagaian besar bersumber pada hasil pengukuran yang berupa data serta kuantitatif sifatnya yang bersifat pengukuran di wujudkan dalam bentuk angka yang disebut prestasi belajar. 
Peran dan keberadaan pondok pesantren sebagai salah satu lembaga pendidikan asli Indonesia memang harus tetap dilestarikan dan diperhatikan perkembangannya, karna kehadiran pesantren di tengah-tengah masyarakat adalah selain untuk memberdayakan masyarakat juga sebagai wadah untuk menyiapkan kader-kader ulama yang mampu menguasai dan memahami al-qur'an.

\section{PROBLEMATIKA PENGAJARAN BAHASA ARAB}

Penguasaan bahasa arab merupakan hal yang sangat penting mempelajarinya bahasa arab merupakan kewajiban agama, untuk memahami ajaran islam dengan lebih baik solat saja menggunakan bahasa arab. Bayangkan jika manusia bebas menyampaikan pesannya dan memiliki akses terhadap media untuk menyampaikan pesannya. Tentu akan terjadi dialog yang akan membuka selubuh kepentingan-kepentingan, terutama yang tidak disadari. Sebab , hambatan yang menimbulkan pertentengan antara manusia atau antar kelompok lebih banyak disebabkan oleh tidak terjadinya komunikasi, sehingga yang muncul hanyalah prasangkaprasangka yang terpendam. Tak heran jika masyarakat, terutama di Indonesia selalu menghadapi konflik akibat terpeliharanya prasangka antar kelompok sosial yang berbeda.

Jika terjadi dialog antara dua kelompok yang berbeda sudah mampu memahami identitas dan budaya masing masing, tetapi masih terjadi pertentangan antara keduanya, berarti ada antagonisme antara dua kekuatan ini, kadang, memang ada suatu kekuatan yang justru mengambil keuntungan dari terpeliharannya prasangka. Kekuatan ini akan terus bertahan selama dialog dan komunikasi tidak terjadi sebab hanya dengan komunikasilah pesan pesan antara kelompok yang berbeda itu akan dapat mengungkap kesalahpahaman kesalahpahaman yang ada. Maka dari itu kita sebagai umat agama islam dan warga Negara Indonesia mayoritasnya agama islam jadi wajib belajar dan memahami bahasa arab.

Lingkungan juga akan memengaruhi berjalannya komunikasi, lingkungan menentukan sikap, anda tidak dapat melakukan diskusi secara efektif di tempat ramai, apa lagi membahas tentang hal hal serius. seorang dosen tak akan bisa menyampaikan materi kuliah secara efektif dalam situasi kelas yang ramai.

Dalam mengajar bahasa antar manusia, efektifitas bahasa juga berkaitan dengan bagaimana menusia memfungsingkan alat alat tubuhnya atau indranya, kemampuan melihat, 
mendengar dan berbicara sangat menentukan bagi terjadinya komunikasi yang lancar dan efektif

Berbicara sebagai tindakan untuk di mengerti yang juga butuh efektivitas agar pesan yang di sampaikan juga bisa masuk secara baik, sebagai proses penyampain pesan berbicara bukan hanya tindakan mengeluarkan suara dari mulut, melainkan juga memosisikan tubuh, menggerakan tangan menunjukan wajah

Gerakan tubuh saat berbicara adalah kekuatan yang tidak dapat diabaikan, saat berbicara di depan, dengan posisi berdiri dengan bebas berjalan, merupakan gaya yang sering digunakan oleh motivator andal, seperti Mario teguh, ari ginanjar.

\section{KESIMPULAN}

1. Peran dan keberadaan pondok pesantren sebagai salah satu lembaga pendidikan asli Indonesia memang harus tetap dilestarikan dan diperhatikan perkembangannya, karna kehadiran pesantren di tengah-tengah masyarakat adalah selain untuk memberdayakan masyarakat juga sebagai wadah untuk menyiapkan kader-kader ulama yang mampu menguasai dan memahami al-qur'an.

2. Problem yang terjadi dalam pembelajaran bahasa arab ialah di karenakan oleh siswa kurikulum, metode, guru dan media pembelajarn. Memperbaiki sikap siswa dalam memberi motivasi dan menghilangkan image bahasa arab yang sulit.

\section{DAFTAR PUSTAKA}

Wekke, Ismail Suardi. 2011. Dukungan sosial, optimism dan prestasi belajar bahasa arab. Makassar: UIN Alauddin Press.

Wekke, Ismail Suardi.2014. Model Pembelajaran Bahasa Arab. Yogyakarta: Deepublish.

Soyomukti, Nurani. 2016. Pengantar Ilmu Komunikasi. Yogyakarta: Ar-Ruzz Media. 